\title{
FOLK MYSTIC: A NARRATIVE OF A POLISH HIGHLANDER CUNEGONDE SIWIEC
}

\author{
Tomasz Kalniuk \\ PhD, Department of Ethnology and Cultural Anthropology \\ Nicolaus Copernicus University in Torun, Poland \\ e-mail: tekantrop@umk.pl
}

\begin{abstract}
This article presents the figure of Cunegonde Siwiec, a folk mystic and a highlander, who lived in one of the villages in Lesser Poland at the end of the nineteenth and the first half of the twentieth centuries. Stryszawa is a linear village located in the Sucha County, an ethnographic region inhabited by the highlanders of Babia Góra. Kundusia - this is what she was called by people around her - became an inherent part of this area, at the same time being considered to be both one of the fellow countrywomen and an extraordinary neighbour. Making use of the available literature, I present in the text relations between Cunegonde and the place of her residence, and on the basis of the field research I show her impact on the environment. The structure of the text is made up of the following three parts: elements of the ethnography of the Babia Gora region, reconstructed fragments of Cunegonde's biography, and the narrative about Cunegonde circulating among the inhabitants of the village and pilgrims. ${ }^{1}$
\end{abstract}

Keywords: Cunegonde Siwiec, folk culture, highlander, mystic

\section{REGIONALITY}

Located in the Sucha County (with the administrative seat in Sucha Beskidzka), the village of Stryszawa along with a few other rural settlements constitutes a ten-kilometre-long linear village. It lies on the hill of Siwcówka and is a hamlet with several houses (only a few of which have their fixed all-year-round tenants). 'Years earlier, a clergyman who came to this area noted that Siwcówka itself lies as if in the centre of an amphitheatre of mountains' (Bartkowski 2008: 14). Its remoteness and the resulting territorial isolation (nowadays, in the era of commonly available cars, the isolation is only symbolic) bring up the association with the history of the area: in the ninth century the territory that belonged to Slavic Vistulans ${ }^{2}$ was an uninhabited forest-covered land (see Krzywda 2010: 14). Good knowledge of the terrain, location next to important communication routes, and a difficult financial situation of the local commu- 
nity seemed to be sufficient factors for people to become robbers. However, the scope of this phenomenon was neither big nor severely perceptible, because the highlanders who later became robbers handcrafted in more distant areas so as to be able to come back "to their own people" for winter. Irrespective of the extent of the phenomenon, the robber-related narrative repeated in the local folklore helped to reinforce the perception of a relationship between shepherds and robbers. This mode of thinking can be perfectly confirmed by a written note from the nineteenth century. Its content leaves no doubt as to the fact that any contact with people from Babia Góra hardly differed from the encounters with the wild. The author himself, Józef August Schultes, an Austrian botanist and a local historian, distastefully wrote the following words about the looks of the inhabitants at the foothill of Babia Góra: 'a cold, dead and addled face expression, because of which the imagination of an artist painter withers away' (as cited in Janicka-Krzywda 2010: 24).

Stryszawa gained a permanent reputation as an area of highland robbers. A powerful example of this is a contemporary crest of Stryszawa, which includes two curved knives. Etymology and history also point to poverty as a motivational factor to lawlessly commit robberies. The old Polish word strysz means either

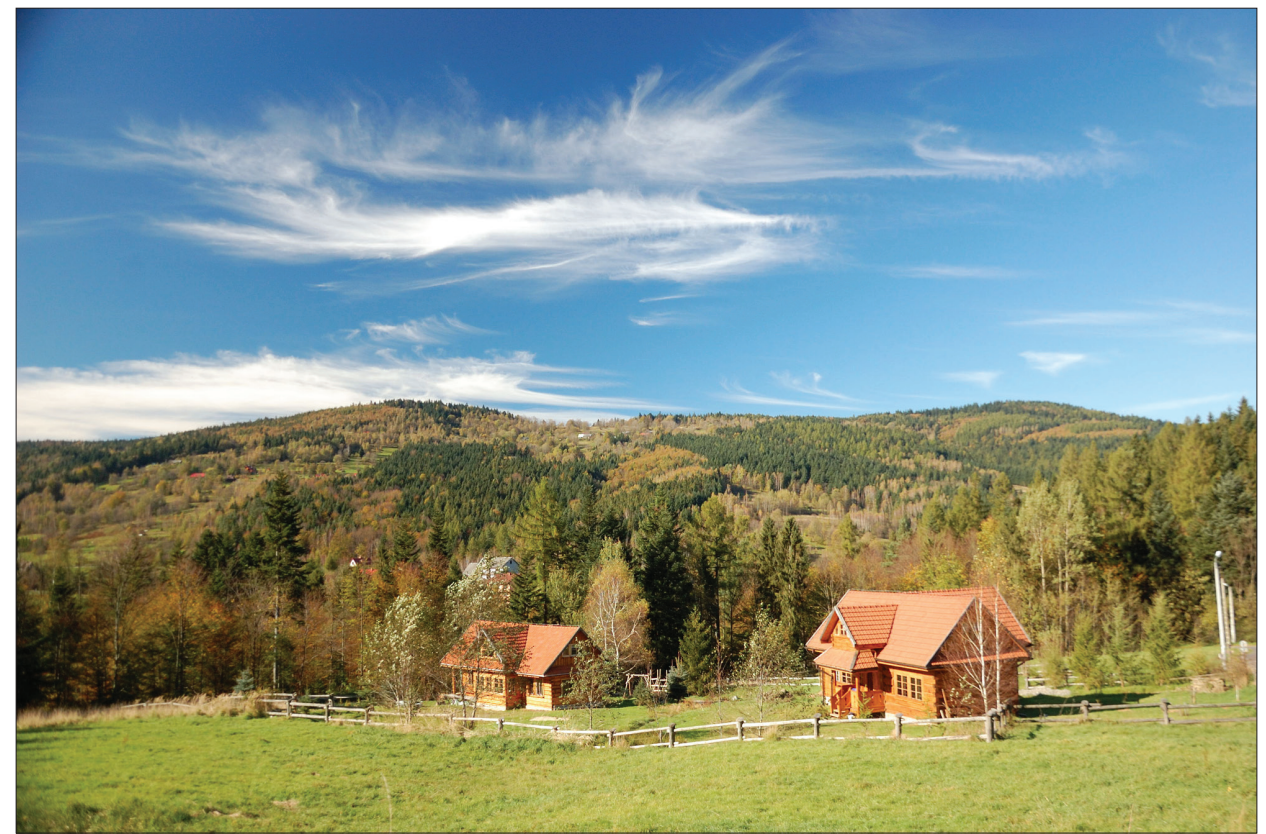

Figure 1. The present panorama of Siwcówka. Photograph by the author 2014. 
a poor settlement or a poor man. A narrative describing a well-known "Galician poverty" gives succour to the above explanation. The inhabitants of Babia Góra definitely needed to face poverty more often than robberies, and this resulted in their ability to develop resourcefulness. Apart from being involved in activities typical for mountainous areas, such as growing crops, breeding cattle, and shepherdry, people in Stryszawa also produced and processed wood. Because of the fact that after 1918 there was not enough farmwork for everyone, people looked for sources of income from handcrafting - cooperage and carpentry. A large number of inhabitants proved able to make wooden toys, which were subsequently sold at local fairs in Sucha Beskidzka, Cracow, or in the area of Silesia Province (Walczak 2002: 40). Nowadays, Stryszawa is an important centre for folk sculpture and toy-making. Apart from multi-coloured "birds of paradise" available to be bought at the Beskidian Centre of Wooden Toy, and the permanently repeated folklore narrative of robbers, Stryszawa is famous for an autochthonic mystic woman, Cunegonde Siwiec.

Figure 2. A contemporary wooden toy from Stryszawa. Photograph by the author 2014.

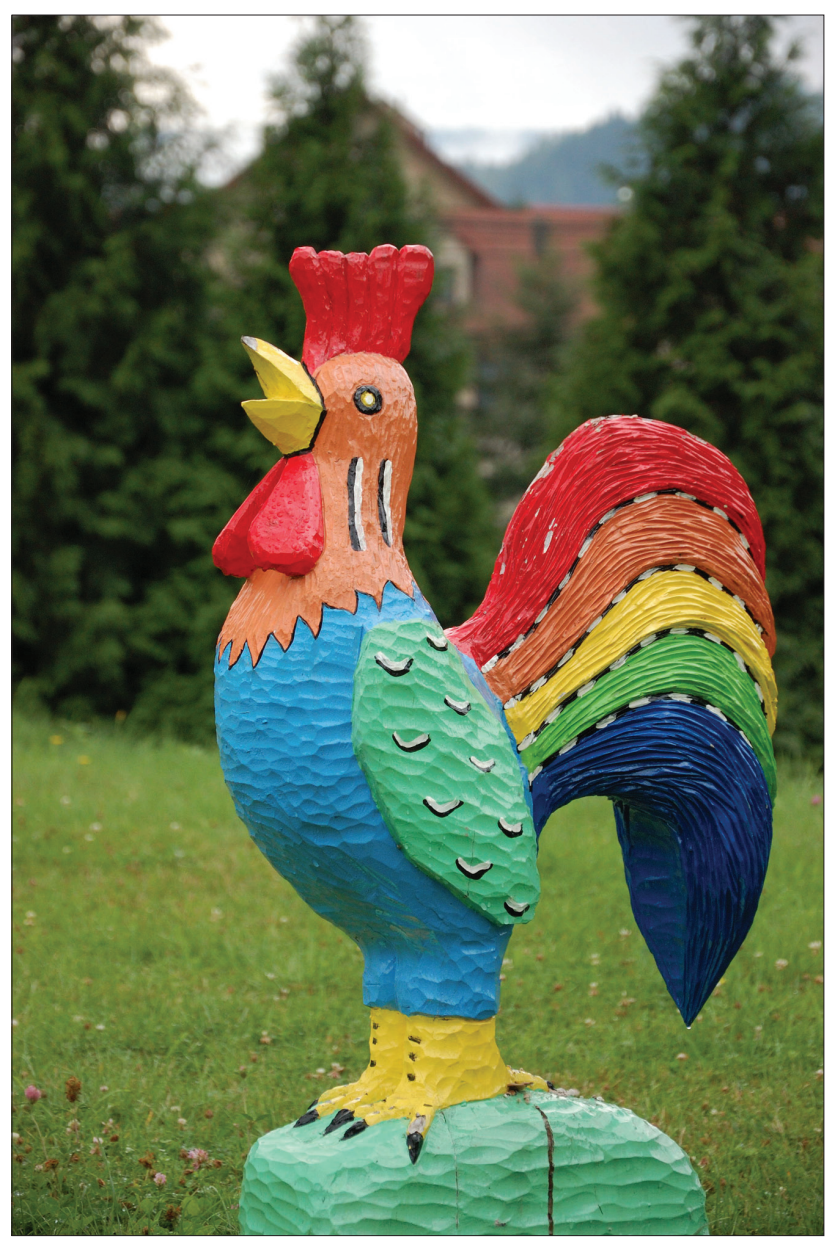




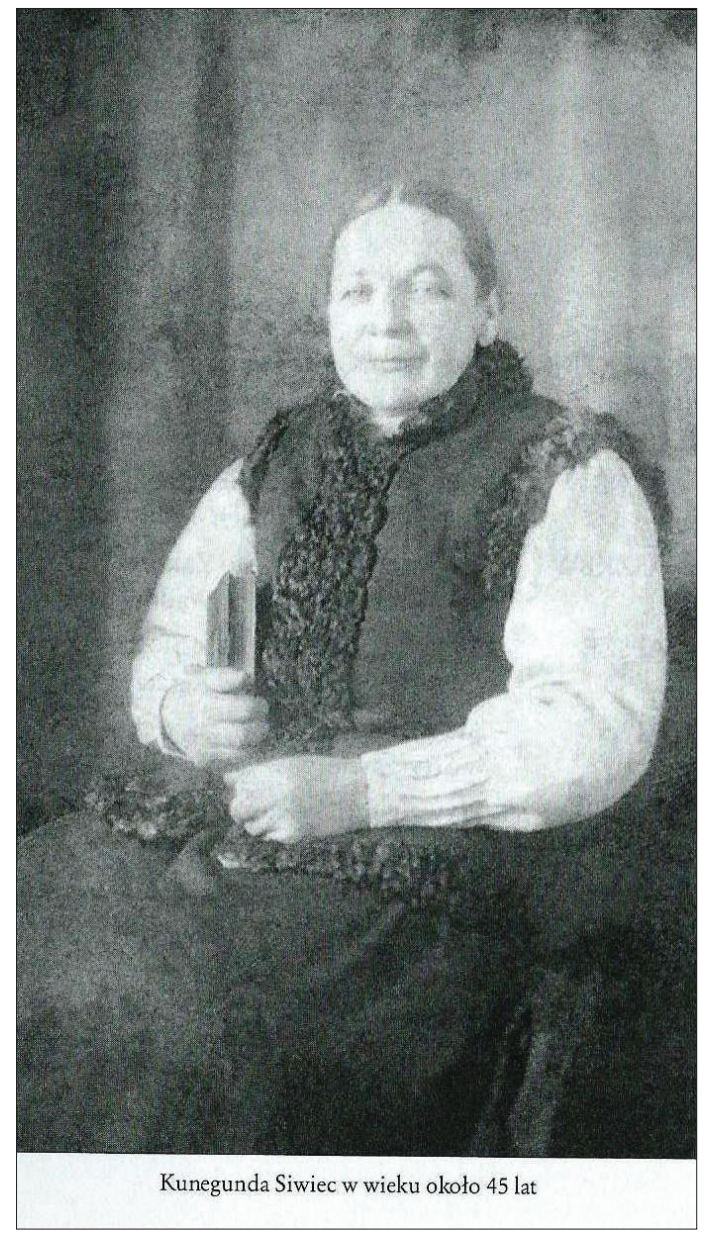

Figure 3. Cunegonde Siwiec at the age of around 45 years (Zieliński 2010: 10).

Her life and her message are organically connected with Siwcówka. The mystic lived and died in a secluded small settlement. She also caused a lasting change in the latter's structure. Siwcówka was converted from an ordinary hamlet into a local religious centre. A convent and a chapel were built there due to Cunegonde and her siblings' generosity. These religious buildings remain living memorials of the mystic and invest the settlement with religious significance. Only recently Cunegonde's mortal remains were taken from the churchyard and ceremonially placed in the chapel. The need for emphasising the place, while describing the highlander's mystic experiences, results from the status given to the place by God. In Cunegonde's mystic revelations God calls Siwcówka the place of His mercy and rest. He promises to remain present there even after Cunegonde's death. 


\section{PERSONALITY}

The idea of Cunegonde's spiritual self-portrait and its connection with the local space evokes the concept of folk religion. This literary term is used with reference to the village community's religious behaviour. Its members were strongly associated with their local natural environment because of living off the land. In the article, the folk religion does not mean pre-Christian beliefs (or their elements or relics; compare to Hukantaival 2013: 102), nor does it indicate a system different from the catholic one. The folk religion forms a specific current within its boundaries (similarly, folk culture is a part of national culture), known as folk piety. The folk piety results from a long-lasting interconnection between the official Roman Catholic Church doctrine and the specificity of the local milieu (Cameron 2010: 6). It is, for example, characterised by the attachment to communal forms of cult resulting in mass, emotional and ostentatious participation in liturgy and paraliturgical services as well as by sensuality that makes the form and the content of the cult equal.

Cunegonde grew up in the atmosphere of folk religiousness and so behaved accordingly (for example, as an illustration of sensuality, she rubbed a sick cow with the picture of St. Thérèse of Lisieux). At the same time, she went beyond the limits of folk piety, developing a personal relationship with God, which placed her in the field of mysticism. Cunegonde was a folk mystic coming from a rural background and living in a secluded settlement, but at the same time she stood out against her milieu because of her profound, individual, and personal relationship with the sacrum (Lat. holy bone). Although her attitude was characterised by subjectivity of her religious experience, it was still connected with her place of living and has resulted in a limited character of her cult, which is typical of folk religiousness. The folk mystic's attitudes are quite similar to the ideals of St. Thérèse from Lisieux (also called the Little Flower). The witnesses' opinions as well as the notes of Cunegonde's supernatural visions testify to both her reverence for the French saint and the practice of "the little way of spiritual childhood" discovered by Thérèse, which consists of simple faith and of trust in God's mercy. God, who spoke to Cunegonde, repeatedly called for taking towards Him the attitude of a little child.

The mysticism of Cunegonde, reduced to supernatural visions, was not known to people in her environment. However, her mysticism treated as an intense life of prayer did not raise anyone's doubts: 'People believed in her intercession' (Zieliński 2010: 107). Cunegonde's favourite saint, St. Thérèse of Lisieux, redefined the concept of mysticism by shifting the focus from ecstasies and visions towards volitional experience of the communion of a person with God (see Stinissen 2001: 88). Kundusia (this is what she used to be called and what 


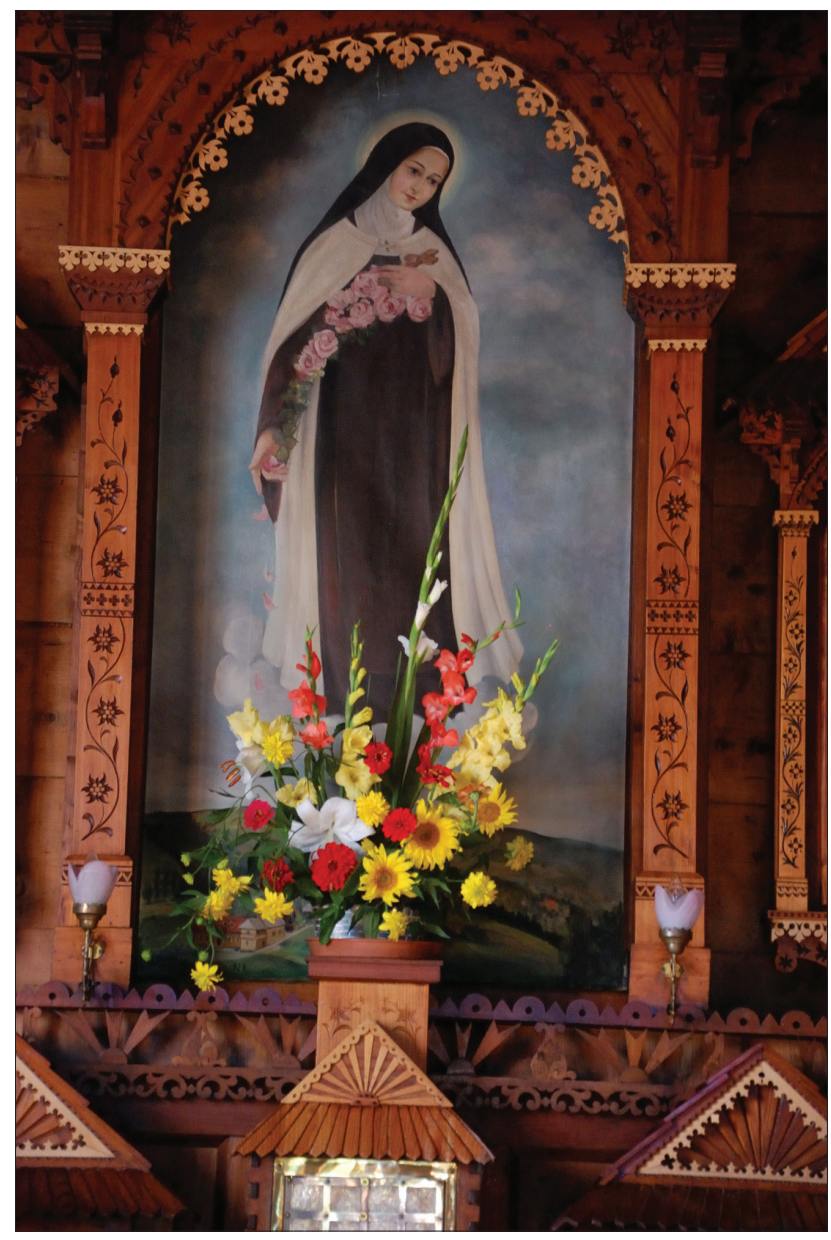

Figure 4. Chapel of St. Thérèse of the Child Jesus in convent. Photograph by the author 2014.

she is referred to also today) lived in unity with God, aware of His permanent presence. People who met her knew that she was different and they watched their female neighbour's long prayers, which was what distinguished her from others. The prayer created an invisible barrier separating her from the group, but at the same time it did not exclude her from the ongoing daily life.

Cunegonde Siwiec is a historical figure inscribed in the history of the land of Stryszawa. According to a record in the Parish Baptismal Register of Saint Anna's Church in Stryszawa, Cunegonde was born on 28 May 1876 as the tenth child of Jan and Wiktoria Siwiec. The biography of Cunegonde and her family is intertwined with the history of the region. Her grandparents were the founders of a new rural settlement, and her father owned a considerable amount of land and had a reputation of being a good landholder. Cunegonde 
gave a part of the inherited land to the benefit of the church and in this way the local space was permanently changed. In 1929 a convent of the Sisters of the Resurrection was built in Siwcówka. It had a Chapel of St. Thérèse of the Child Jesus, which was open for people. ${ }^{3}$ In the new place, nuns carried out educational and charitable activities as part of the operation of the Scientific and Educational Centre. Orphans from all over the country and young girls from the neighbourhood started to come to Siwcówka to be taught how to sew, embroider, and do farmwork. ${ }^{4}$ Cunegonde is present in the recollections from that period of time, which are recorded in the chronicles of the convent and in the collected private archives (see Donajska 2014: 42-62). The records highlight, above all, her unique piety that was expressed by the intensity of her prayer:

I remember-says Sister Lucjana Maryka - that sometimes she had prayed in the chapel for so long that her niece, Hanusia Leśniak, came there to take her out for fear of her health. When we saw that she had already stayed in the chapel for a few hours, we also sometimes invited her to come round for a meal. (Zieliński 2010: 88-89)

Not much time passed until the chapel was to become Cunegonde's second home. The home in which she was born and died did not stand out from the others. The house was a typical chimneyless hut and was equipped with a chimney some time later. In the same way, Cunegonde fitted in the ordinary life landscape of the people from Siwcówka. Together with the women from the settlement she fetched water from a stream, washed the undergarments, using wooden washing bats, and helped with farmwork. Taking part in the everyday life of the then Stryszawa, especially during World War I, involved coping with numerous adversities, such as requisition of goods for military use, hunger, and epidemics. In the settlement devoid of men $^{5}$, it was women who assumed the responsibility for maintaining houses and fields:

Long years of hard work and taking care of the family and the house left numerous traces on Cunegonde's body. They were on her shoulders, feet, and knees. Most of them were, however, on her hands. Hard, cracked skin on her hands was a living proof of everyday hardship. (Zieliński 2010: 41)

The rhythm of life at that time focused around the necessity to work, with breaks only for sleeping and some occasional holidays. The Siwiec family were considered to be decent, peaceful, and hardworking. There were several inns providing services to the inhabitants in the area of Stryszawa, but the Siwiec family did not use them. They lived in a profoundly religious atmosphere, which, according to what Władysław Orkan once wrote about highlanders, was not typical for the traditional folk culture. Orkan stated that generally the life of highlanders was 'permeated by religion to a small extent' (Orkan 1946: 125). 


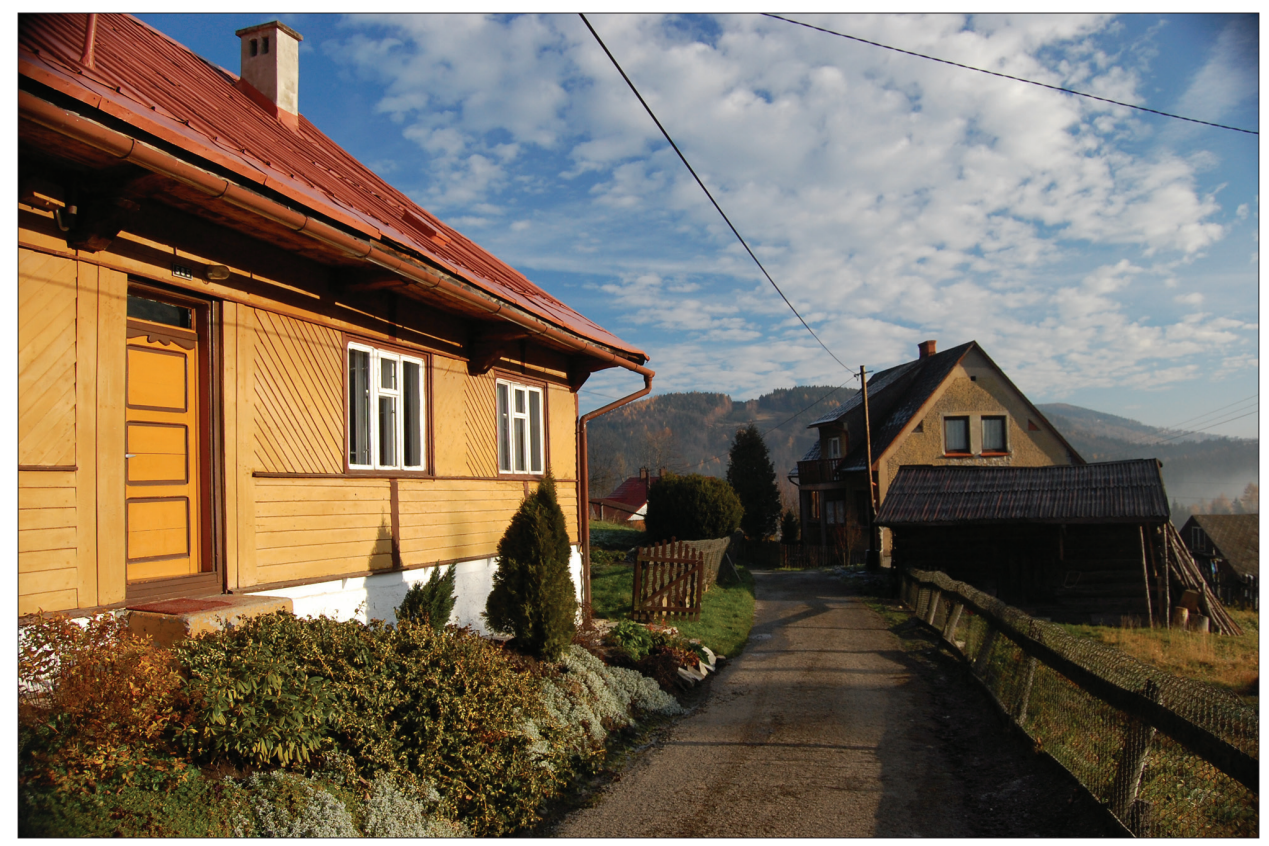

Figure 5. Cunegonde's wooden house. Photograph by the author 2012.

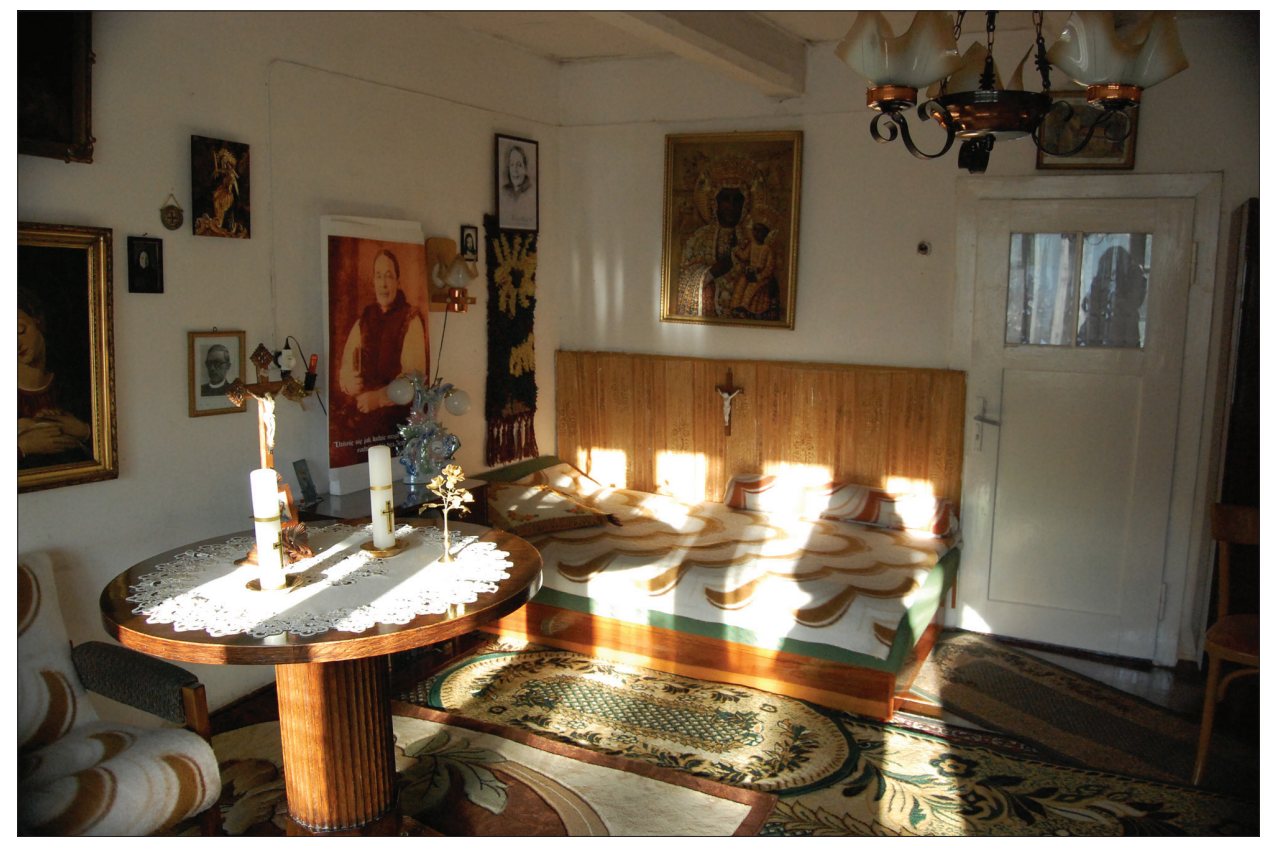

Figure 6. The interior of Cunegonde's house. Photograph by the author 2012. 
This opinion is in line with the statement of Ludwik Stomma, who observed, in his analysis of folk religiousness, that there was a low proportion of spiritual people in the rural areas in Poland (see Stomma 2002: 274). The Siwiec family belonged to a group of believers who showed more lively interest in the matters of the Church. They read plenty of newspapers and Catholic books, which was by no means a typical behaviour of people living in rural areas. It was usually Michał, Cunegonde's younger brother, who did the reading, while others listened and later shared their afterthoughts (Cunegonde and the majority of the family and neighbours were half illiterate). Among the books read at their house were some requiring careful and reflective recipients, for example, the works of Carmelite saints. The books were borrowed from the monastery library of the Carmelite Fathers in Wadowice. Contacts with monks and their spirituality soon resulted in Cunegonde's becoming a member of the secular branch of the Carmelite Order, where she was known as Sister Thérèse of the Child Jesus.

Undoubtedly, Cunegonde got her first religious education in her family home. ${ }^{6}$ The everyday atmosphere of Siwcówka also taught her higher values, 'because her faith in God, in His truths and laws was at the same time the basis of the whole philosophy of life and the standard of behaviour' (Bartkowski 2008: 16). The general faith in God's protection was common in the village and a large number of inhabitants participated in religious practices. But this was not enough for Cunegonde, that is why she took a private vow of chastity and, as a consequence, she remained unmarried. Such a choice gave rise to a concern since the traditional approach to life focused on increasing the value of family business. According to William Thomas and Florian Znaniecki, one of the constitutive features of the rural community was marriage, while spinsterhood and bachelordom resulted in the alienation of an individual (Thomas \& Znaniecki 1976 [1918]: 110-124). In the case of Cunegonde, the decisive factor for choosing a solitary life was not her unfavourable fate but an exceptionally strong spiritual experience. The decision to remain single in order to lead a more devoted religious life was probably made at the age of twenty. Father Bernard Łubieński, a well-known retreat preacher, conducted popular missions in Stryszawa at that time. 'Such Kundusia came back from these missions and such she will remain for the rest of her life,' wrote her spiritual director (Bartkowski 2008: 17).

The inhabitants of Siwcówka accepted Cunegonde's unusual choice and, what is more, treated her with respect. She gave advice to people, some of whom came to her voluntarily and some through referral by a priest. The number of people seeking advice increased especially after Cunegonde had completed appropriate courses to become a lay catechist, the so-called sidziniarka ${ }^{7}$. Women who belonged to this movement were respected mainly because of the fact that 
they had made their personal vow of virginity and were well informed in local realities. 'They knew well what a highlander's soul is like, so their impact on the highlanders who were "puffed up", distanced from the Church or in conflict with one another was sometimes more effective than that of their parish priest' (Zieliński 2010: 56). Pious women and also tough introverted men asked Cunegonde to help them prepare for the confession. She had courage to tell them the truth and maintain respect at the same time. Cunegonde's sincerity and kindliness won her the ear of the inhabitants of Babia Góra, but obviously only of those who wanted to listen to her, because there was also a group of mockers who were distrustful of her piety. 'There was a rumour around that she talked to Lord Jesus. Some laughed at it, others wondered,' recalls Wiktoria Janik (Zieliński 2010: 94).

In Cunegonde's lifetime, her extraordinary experiences were known only by her household members and the nuns with whom she maintained closer contact. Father Bronisław Bartkowski, Cunegonde's confessor, soon joined the circle of people who were aware of her case. The priest had been listening to her confessions for many years and he knew that Cunegonde was a spiritually mature and emotionally balanced person. An unexpected confession about the voices she had been hearing, persons she had been seeing, and conversations she had been holding disturbed the priest's current image of the penitent. Although he ruled out hallucinations and did not suspect a lie, he was far from being uncritical and decided to investigate the whole matter. A sign that confirmed the authenticity of the visions was a confession made by one of Siwcówka inhabitants, who had avoided confessionals for years. Not disclosing the details (the idea was that he wanted to hear a confession of a certain person on a certain day), Father Bronisław told Cunegonde to pray. In due time, he was given a positive answer.

The third day of May [of 1943] arrived. After the devotion I sat in a confessional and who should I see next to the confessional but this sinner? People started to slowly leave the chapel and then the man stood up and instead of heading for the exit, he stepped up to the confessional.

(Bartkowski 2008: 30)

This situation combined with the direct observation of Cunegonde's life made Father Bartkowski confirm his conviction that her life experiences were of supernatural nature. It must be added that he could clearly distinguish her piety from unhealthy devotionalism: 'There was nothing hothouse, nothing bookish, nothing for show,' he wrote (Bartkowski 2008: 20-21). The priest provided Cunegonde with spiritual assistance until her death on 27 June 1955. During this time, he observed the spiritual growth of the penitent, whose increasingly clearer mission was to pray for sinners and co-suffer with Christ. After a period of intense verbal apostolate, Cunegonde embarked on a path towards expia- 
tion: 'Over the years there were fewer and fewer opportunities to talk about God. On the other hand, situations involving spiritual or physical suffering began to mushroom on her way' (Zieliński 2010: 101). First, she lost sight in her right eye as a result of trachoma ${ }^{8}$. Then, more and more frequent pains in her limbs revealed bone cancer, which had made it completely impossible for her to leave home since 1948. In his recollections related to that period of time, Father Bartkowski compares the bed in which Cunegonde had lain for seven years to the wood of the cross on which Jesus had suffered. Because of devastating pain, Cunegonde was not able to turn over or sleep and in spite of the fact that she was always brave and patient, 'she could not refrain from screaming' (Bartkowski 2008: 22). The priest confessed that the suffering did not deprive her of serenity:

There was constant peace and a bright smile on her face except when she suffered severe pains. And although it would seem that she needed much comfort herself, it was her who gave comfort with all her ardent heart to those who came to her with their small and big worries. (Bartkowski 2008: 23)

Cunegonde's descriptions written down by the priest constitute the testimony of her supernatural experiences. The highlander did not know that the notes taken down by her confessor would ever be made public. On the other hand, Father Bartkowski did not strive to promulgate the materials although he was aware that writing down Cunegonde's inner experiences was valuable for spiritual formation (see Zieliński 2010: 93). As a consequence, for many years the text had been shared among only a handful of people, especially the Sisters of the Resurrection (Donajska 2014: 59). The publication of the notes ${ }^{9}$ attracted keen interest both among the clergy and lay people, who in 1996 initiated the efforts to raise Cunegonde to the honours of the altar. Along with the preliminary works undertaken by Polish canonists, the Friends Association for Cunegonde Siwiec was founded in 1998. Its members organise annual pilgrimages to her tomb in Stryszawa, which fall on the day of the feast of Our Lady of Perpetual Help. Moreover, in cooperation with the Carmelite Order, they try to explore and promulgate the spirituality of the highlander woman. An example of this was, among others, a scientific conference devoted to various aspects of her spiritual path, held in 2006 in the Carmelite Spirituality Institute in Cracow. On 21 December 2007, the Metropolitan of Cracow, Cardinal Stanisław Dziwisz, officially opened the beatification process (see Zieliński 2010: 116). However, according to Ewa Leśniewska, 'on Friday, 28 October 2011, there was the closing of the diocesan investigation into life, virtues, and opinions on the sainthood of the Servant of God, Cunegonde Siwiec, of the Secular Order of the Discalced Carmelites, who died in 1955 in Stryszawa, near Sucha Beskidzka, in the Archdiocese of Cracow' (Leśniewska 2011). 


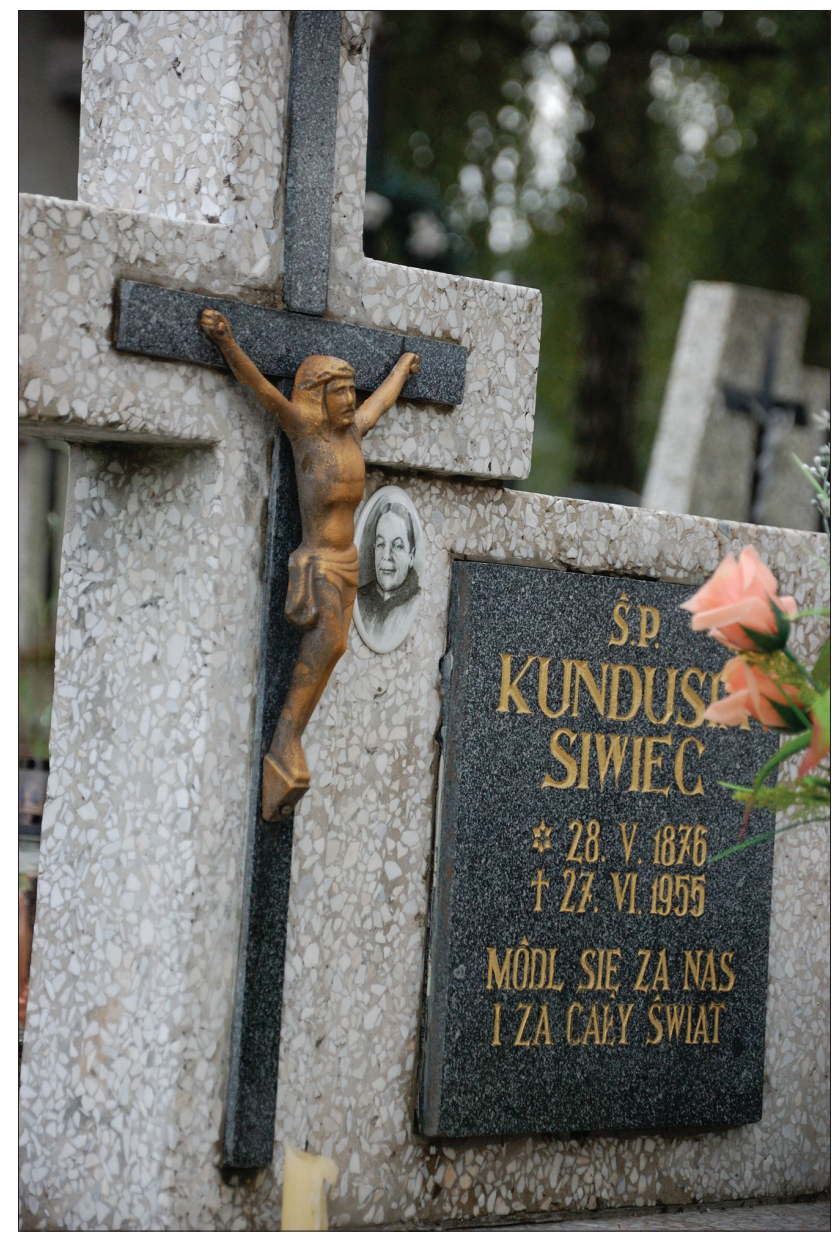

Figure 7. Cunegonde's tomb near the church of Saint Anna in Stryszawa. Photograph by the author 2014

In the Catholic religious observances, reverence of saints who are not accepted by the Church authority is rather rare, and any such occurrences are not longlasting. The required standards in this respect distinguish Catholicism from the Orthodox Church and from some sects where there may be a grassroots veneration of saints. As a result, Cunegonde's case would not spread among believers unless it was approved by the clergy. Roy Rappaport claims that the confirmation of sainthood consists of a few elements: apart from the faith factor and using the Ultimate Sacred Postulates, the believers' involvement in liturgy is crucial (Rappaport 1999: 288, 396). The case discussed in the article first requires the church authorities' consent. As a result, both the dynamism of the faith and the extent of the folk mystic's cult are connected with the progress of the church committee's work. At this point in time, as since 2007 there has been a beatification process in progress in Rome, a certified miracle 
is required. Without it, the religious veneration will remain only at the current, local level. The recent events show that some development is to be expected. In November 2016, Cunegonde's mortal remains were exhumed, then put into an ornamented sarcophagus, taken from the parish churchyard and placed in the chapel in Siwcówka. The procedure involved preparing bones to be made into relics when the beatification takes place (see Exhumation).

\section{INFLUENCE}

The content of Cunegonde's dialogues with Jesus, Mary, and other saints is consistent with the so-called 'little way of spiritual childhood', which was initiated by a French saint, Thérèse of Lisieux. Its novelty comes down to exercising, in one's religious life, the attitude of a small child towards God. Feeling incapable of practising a higher level of asceticism, St. Thérèse stuck to the Gospel incentive to remain small, and elaborated on the thought of the necessity to completely trust in God: 'For this [she wrote about gaining sanctity] I do not need to grow. On the contrary, I need to remain small and become even smaller' (Stinissen 2001: 96). Lord Jesus replied to Cunegonde's concerns that 'weaknesses disappear in His love like sparks in the air, and what He really wants is just to reciprocate love: Like a child who does not think about anything else but loving their parents, and the father thinks about the child's needs, so you do as if nothing else existed in the world but Me and you' (Bartkowski 2008: 212). Cunegonde's conversations with Christ and saints relate to the aspect of trusting in God's mercy, which was the basis of Little Thérèse's spirituality. Thérèse herself during a supernatural vision told the highlander the following words: 'Even whipping and penance will not equal childlike love. God is leading you through the path of childlike trust' (Bartkowski 2008: 208). This was confirmed by Jesus when in one of the dialogues he told Cunegonde: 'Go through the path which was chosen by me and which was recently started by my bride Thérèse. This path of love pleases me most' (Bartkowski 2008: 60). Similar to the French saint, for whom the act of dedication to the merciful love was a breakthrough (Stinissen 2001: 89), Cunegonde also made her life an uninterrupted act of love. She gave herself entirely to God, who was suffering from human anger and ingratitude, so as in this way to become the vessel for His mercy:

My daughter, I love those who love me and I wish to be loved with clean, immaculate and sacrificial love. I exalt such souls above the whole world and on these souls I pour my love, which others despise. Indeed, I pour on these souls my great love and even greater love, because these souls please 
me and disarm my justice aimed against sinners. Through these souls I pour my mercy on the whole mankind. (Bartkowski 2008: 192)

In Poland, the meaning of the Divine Mercy became more important owing to holy sister Faustina Kowalska, who lived in the times of and near Cunegonde in Łagiewniki district in Cracow. An ordinary nun of the 'second choir' (see Czaczkowska 2012: 124) was explicitly called by God 'the secretary of His mercy' (see Kowalska 2010 [1981]: 430). As in the case of Thérèse and Cunegonde, Jesus assured her that 'love fills up the abyss that exists between His greatness and her nothingness' (Kowalska 2010 [1981]: 175). Struck by the profound awareness of God's goodness on the one hand and human sin on the other, Faustina encouraged everyone to trust in the Divine Mercy. In one of her meditations, she said to Jesus: 'I doubt that You will pardon my numerous sins; my misery fills me with fright' (Kowalska 2010 [1981]: 396). In response to this, she heard a voice: 'My mercy is greater than your sins and those of the entire world' (Kowalska 2010 [1981]: 396). Having experienced numerous hardships, the nun made a confession to God:

I fly to Your mercy, Compassionate God, who alone are good. Although my misery is great, and my offences are many, I trust in Your mercy, because You are the God of mercy; and from time immemorial, it has never been heard of, nor do heaven or earth remember, that a soul trusting in Your mercy has been disappointed. (Kowalska 2010 [1981]: 460)

Apart from obvious theological similarities, the revelation of the mystery of the Divine Mercy to St. Thérèse of Lisieux, Cunegonde Siwiec, and Faustina Kowalska contains an analogy in the promise of its continuation. In her last months of life, which she spent suffering from tuberculosis in the infirmary, Thérèse stated that her heaven would be to do good on earth: 'I cannot let myself rejoice, I do not want to rest until there are souls to be saved' (Agnes of Jesus 2014: 107). Sister Faustina wrote in her Diary: 'I feel certain that my mission will not come to an end upon my death, but will begin' (Kowalska 2010 [1981]: 113). To Cunegonde, on the other hand, God announced that when she goes to heaven to His Father's land, He will stay in her father's land, in Siwcówka: "This is the place where I will rest and from here I will spread my mercy across the whole world through my chosen ones, and I will confirm my mercy even with miracles' (Bartkowski 2008: 44, 216).

This correspondence of fates and thoughts was noted by pilgrims as well as by theologians, who stated that in the case of Cunegonde Siwiec we can notice an interesting symbiosis (see Zieliński 2010: 116).

As one reads the revelations of Kundusia, they can find lots of expressions which are identical or nearly identical to the "Diary" of Saint Faustina 
and the same profound simplicity: "talk to me", "beg, love", etc. Lots of thoughts expressed literally using the same method. (a 52-year-old woman from Wrocław)

As the chaplain of the Sisters of the Resurrection admits himself, in the beginning he perceived this similarity negatively:

As soon as I came here, I plunged into the notes of "The place of my mercy and rest", I looked for something original in those revelations, but I did not find anything. All revelations of that kind, conversations with Lord Jesus are similar to one another, that is why I was slightly disappointed, but what new things should I look for? (a 68-year-old man from Stryszawa)

Marcin Jakimowicz wrote in the Gość Niedzielny: 'We will not find here any sensation or a ready script for the "Beyond Belief" TV programme. It is a dialogue between a lonely woman and a human-deserted God' (Jakimowicz 2009).

A few literary and film works dedicated to Cunegonde's life have been made, which are available today. The fall of the communist system in Poland in 1989 brought socio-political, economic as well as religious freedom. The availability of the press and literature, including catholic media, has been enhanced due to the freedom of expression and religion guaranteed by democracy. (More about the changes in Polish Catholicism after the fall of communism, see in Borowik 2003.) The first diary of Cunegonde's visions was published in the early 1990s. In Poland, in post-communist times, when the public, political and economic life became subject to pluralism, also the religious sphere began to demonstrate some variety. The status of the Catholic Church changed. Although still dominating, it became one of many religious institutions, so Catholics became more selective (Bruce 2013 [2011]: 13; Parsons 1960: 304). Believers started to be exposed not only to one pervading value system but to many of them. Polycentrism and diversity in the modern type of society influenced the area of religiosity (Riis \& Woodhead 2012 [2010]: 174). Within the Polish postcommunist religiousness, 'the mystic from the mountains' found her followers in the Catholics interested in the message concerning 'the little way'. Thus, Cunegonde's spirituality, or rather her 'spiritual childhood' gains recognition not so much among mass audiences, but rather among specific groups of Catholics. Gradually, Cunegonde's case has become an object of interest for clerical and lay people from outside Siwcówka and Stryszawa.

There is a polarisation of attitudes towards Cunegonde among local people, ranging from personal devotion to whispered criticism. It is an example of otherness manifesting itself, as pointed out in numerous studies, in a bipolar fashion: tremendum et fascinans (Otto 1958: 41-49; Caillois 2001: 48). 
People from here have their own opinion of Kundusia, sometimes very critical, because for them she was as any other woman; they did not know she had conversations with Jesus, as these were very intimate matters. Apart from that, she was slightly original because of the fact that she decided not to get married. (a 68-year-old man from Stryszawa)

Helena Stańczyk, who in 1987 was the first to be captivated by Cunegonde's spirituality and took up collecting information about her from people, firmly rejects the veracity of negative opinions:

Those who had a negative opinion of Kundusia did not want to talk to me at all, or when I asked them to tell me the whole story, for example, one about a female servant to whom the Siwiec family allegedly did not pay and she escaped through a window, they did not want to tell me that and, especially when I demanded their signature, they would not agree. If a person did not want to sign, then for me it was just gossips which I did not listen to. (an 84-year-old woman from Jelenia Góra)

For the majority of people who remembered Cunegonde, she was a pious and good grandmother, who did not differ from others in terms of appearance:

There were lots of Kundusias there, lots of such old women wandered around, but this one was kind of a real one, she went to church in Siwcówka. I was about fifteen years old at that time, so I did not waste my time on old crippled women. Nothing marked her out then but the fact that she was a spinster and had a large plot of land, fields, and forests; now it belongs to the sisters. (an 80-year-old man from Stryszawa)

A woman from the neighbourhood states:

She was so, so.... kind-hearted. Even her close relative says that kids would go under her window and sing such naughty songs, and Kundusia would give them a candy. She was so warm to interact with; you could talk to her like to a good granny. (a 74-year-old woman from Stryszawa)

Another respondent says: 'Personally, I cannot say a bad word about Kundusia, as she was a good woman; she prayed in such a way that probably no nun here can pray like her' (an 82-year-old woman from Stryszawa). On the basis of the heard narrative, the chaplain extends Cunegonde's piety to the whole house: 'The Siwiec family, as I was told, were all very pious, especially Kundusia's brother, Michał' (a 68-year-old man from Stryszawa).

Negative opinions mainly relate to the fact that Cunegonde donated a plot of land to the benefit of the convent. 
Because people here are so land-oriented and don't understand how it is possible to give away the land to someone outside the family. ${ }^{10}$ Did they finally understand that there is nobody to manage the land and the fields are vacant? Don't I know about it? (an 88-year-old woman from Stryszawa)

People, even so closely related, said that they [the Siwiec family] were not good. But they wouldn't say why. There was a very poor family and the father was a heavy drunkard and would constantly come to them to fetch something. The Siwiec family did not want him to drink so much and take things out of their house, because it was not fair. How much longer was it to go on? And when he borrowed something, it was for keeps. People still say that in the place where the convent is, it is not Kundusia's patrimony, but her neighbours'. (a 74-year-old woman from Stryszawa)

A man from the lower village of Roztoki states: 'Nobody knows anything about Kundusia there and will say no good word of her. Why? You had to work there, she was alone, had a lot of land and needed help, but where did the money come from?' (an 80-year-old man from Stryszawa). One of the women speaks out about it, considering the sphere of sacrum and the perspective of spiritual combat:

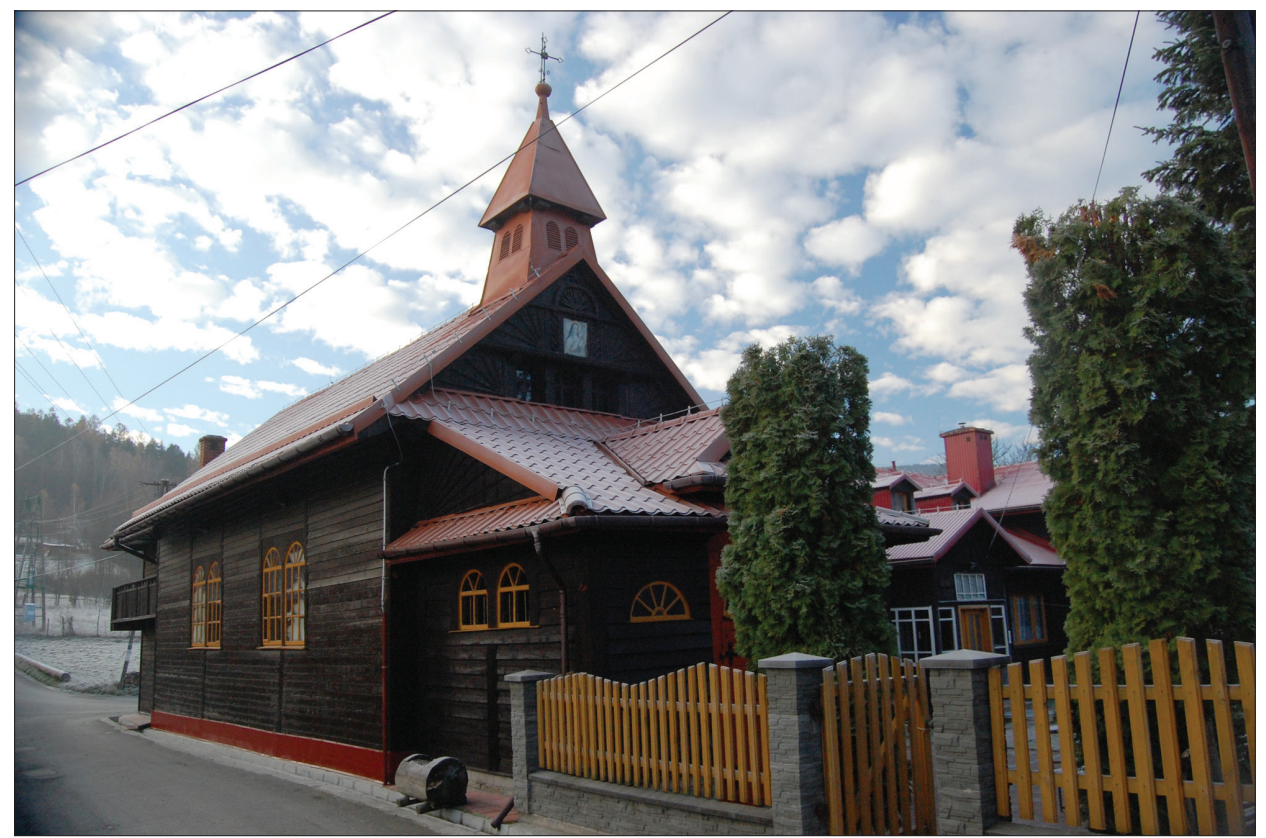

Figure 8. The local convent of the Sisters of the Resurrection in Stryszawa. Photograph by the author 2012. 
Where there is the good and the sacred, there are always lots of evil spirits around. People in the village were jealous of them [the Siwiec family], because they had everything. There were lots of them in the house and they grew wheat and potatoes, and Kundusia's brother Michatek was a great cooper, so they had money from that. (an 82-year-old woman from Stryszawa)

A change in the social structure of the village, a generational change, and progress in the beatification process of the Servant of God Cunegonde Siwiec result in the prevalence of positive opinions: 'People didn't know Kundusia and now it is changing because of books' (a 74-year-old woman from Stryszawa).

Now people's attitude is to think that there was something going on here. When there are natural disasters around, like storms or fires, and nothing happens here in Siwcówka, even local people who remember Kundusia say that it is because of her taking care. (a 59-year-old woman from Stryszawa)

A woman taking care of Cunegonde's house sees it in a similar way:

It happens now that when I sometimes meet somebody and ask them where they're from, they say that they're from Stryszawa, which was extremely rare before, because Stryszawa was not fond of her. (an 88-year-old woman from Stryszawa)

A village lost in the mountains with an inglorious past due to robbers and the village's small settlement isolated more than any other, located on the former Austrian-German border, cumulates various and sometimes contradictory threads of description. When phenomenologists write about otherness, they underline its relational character, which can be compared to a knot (see Waldenfels 2002: 70). Siwcówka demonstrates this duality, which is indicated by the results of research cited in this article. One can observe that the answers of the respondents contain the transformation of impressions and of the settlement's image:

For me, the whole Stryszawa was a backwater with old wooden houses; then I took it as great poverty. I was afraid when I was to come here years later, because I had this image encoded in my mind. Once I came back here, I saw a different world and met different, civilised people living in nice houses. I also perceived the convent differently; in those times it seemed so obscure, old and mysterious. And the mystery that I discovered was Kundusia, her contribution, her idea. Everything became close to my heart and at once I found my feet; I felt as if I had always been here. (a 59-year-old woman from Stryszawa) 
Enchanted by the history of Siwcówka and newly acquainted with the narrative of the folk mystic, pilgrims claim that 'this place is amazing and, above all, one can feel that it is a place of prayer' (a 52-year-old woman from Wrocław). A woman from Cracow, who has regularly visited this place for forty years, and a 72-year-old man living for several years in Ruda Ślacska, Silesia Province, who thinks that being in Siwcówka is 'like being in a fairy tale', unknowingly confirm the opinion of the chaplain (a 68-year-old man from Stryszawa), who has made a claim that "this area is a kind of "genius loci", in many ways related to various religious events from the past and today'. Mother Superior of the Sisters of the Resurrection also notices that Siwcówka is unusual. She remembers that initially her focus was placed on a historical wooden chapel dedicated to St. Thérèse of the Child Jesus: 'The chapel, which seemed so full of spirit and prayer, was a strong asset. This asset was the awareness of the fact that Cardinal Wyszyński and Cardinal Wojtyła prayed in this chapel' (a 59-year-old woman from Stryszawa). Over time, the amazement expanded, covering the following elements:

Kundusia, our Mothers Foundresses, John Paul II and Cardinal Stefan Wyszyński make up the whole environment, in which I feel good. The fact that here in Siwcówka there have been so many important people must be some God's plan. (a 59-year-old woman from Stryszawa)

How to explain this spiritual richness?

If you take, even in Poland, some places of revelations, it turns out that they are all on hills regardless of whether the place is a village or a city. Take Saint Faustina - the first revelation of Jesus took place in Płock, a city located on a hill, and here too is a hill, silence, seclusion. I have already been wondering about this a few times, because it is something of essence. Lord Jesus went uphill to pray. All important events in the life of Jesus, and contemporary events too, take place uphill, in private. Being uphill is like being closer to God. You could look at it from different perspectives, but we also have to take into account the fact that indigent God-reliant people are closest to Him. As you can read or hear from different sources, Kundusia's family could be wealthy, but they could share with others, helped the priest reach priesthood - they paid for him with the money they got from selling milk, cheese or eggs. ${ }^{11}$ When the sisters came, they looked after the girls who didn't have anything, as then it was Kundusia's family that provided everything. This family left everything behind. They were poor, closer to God. We must also analyse it from this point of view. Anyway, this was a god-fearing family; if one could read, then they read to everybody the Bible, the works of Saint Thérèse and John of the Cross. And 
what does John of the Cross say but: "nothing, nothing, nothing", nothing for oneself, nothing for the mind, just emptying of oneself. (a 59-year-old woman from Stryszawa)

As concerns the analysis of the ideas about the universe, anthropological studies prove that natural topography with distinctive points often gave rise to carrying out religion-tinted evaluations of space. Mountains dominating in the natural landscape gained a strong symbolic meaning. They were a popular motif in mythologies of different cultures and constituted a part of their vision of history. Universalist and traditional religions underline the spiritual functions of mountains and caves (see Eliade 1997 [1988]: 14-21). Contradictions present in a mountainous landscape facilitate thinking oriented towards the other and towards the sacred, which is often described as ambiguous (see Benedyktowicz 2000: 134; Bornemark \& Ruin 2012). Ambivalent concepts and feelings related to the perception of mountains, their horror and beauty, are parallel to the narrative about the creatures living in the mountains, such as gods, demons, and saints. The presence of the latter in human-unfriendly places, which were considered to be evil-haunted, resulted in the sanctification of such places (see Adamowski 1999: 133-136). In this context, the example of Cunegonde Siwiec is very meaningful. The god-fearing highlander from Siwcówka was famous for, among other things, her beneficial influence on the surroundings. The witnesses remember that one of her abilities was to tame the fiery nature of the inhabitants and pacify frequent arguments. Some people from Siwcówka believe that Cunegonde protects this area. The chapel located on the outskirts of Siwcówka reminds them of the prayers of their extraordinary neighbour, who miraculously saved them from the German occupants. ${ }^{12}$ 'Is a miracle going to happen?' I was asked by one of the inhabitants who anticipated my interest in the folk mystic. It is because the manifestation of a miracle will be decisive for further proceedings in the beatification process of the Servant of God.

\section{ACKNOWLEDGEMENTS}

The research was part of a grant for young scientists titled "Genesis and development of new places of religious cult in contemporary Poland based on the example of Stryszawa village (Sucha County, Lesser Poland Province)", carried out at the Department of Ethnology and Anthropology of Culture of the Nicolaus Copernicus University in 2014. 
Figure 9. The Chapel of the Heart of Jesus on the outskirts of Siwcówka. Photograph by the author 2014.

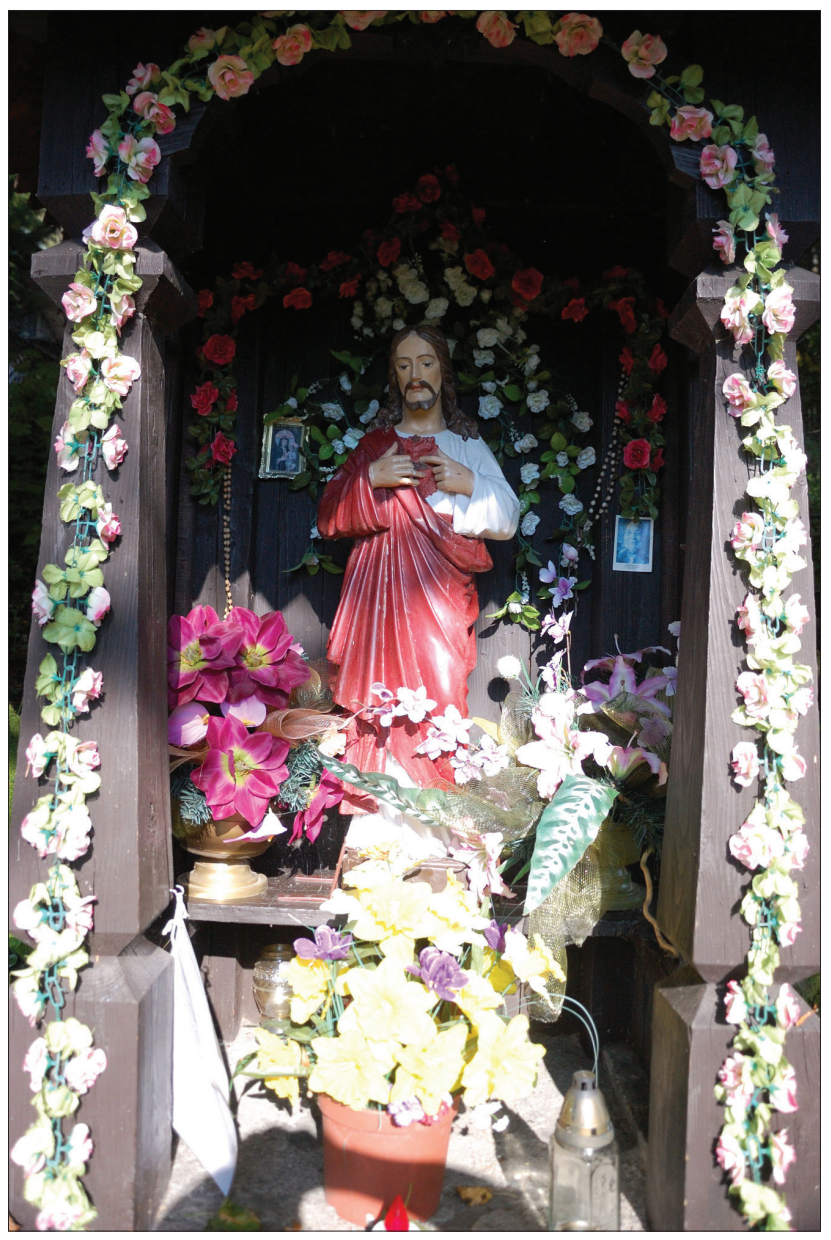

\section{NOTES}

1 This is a revised version of an article published in Polish in the Polish journal Literatura Ludowa in 2015 (Vol. 2, pp. 53-64).

2 A medieval west-Slavic tribe in Lesser Poland.

${ }^{3}$ Cunegonde had a dream, in which Saint Thérèse was dropping rose petals from the sky onto the neighbourhood. Adam Malicki, a painter from Warsaw, made a painting for the chapel on the basis of that dream (see Zieliński 2010: 85).

4 The long-term work of the nuns was definitely ceased by the decision of the authorities of the Polish People's Republic (PRL) in 1961 (see Walczak 2002: 121). 
5 They were forcefully recruited to the Austrian Army, in which the military service lasted from eight to fourteen years.

6 Once again this fact contradicts the statement made by Władysław Orkan, who wrote about highlanders that 'a house in a village is not where you get education' (see Orkan 1946: 130).

7 A colloquial name for women gathered around Father Wojciech Blaszczyński, a parish priest from Sidzina, who helped her with pastoral duties among people.

8 Bacterial inflammation of the conjunctiva and cornea.

9 The first book was published in 1995.

${ }^{10}$ Plenty of descriptions of folk cultures mention respect for the cultivated land as an important feature of a culture. An individual in rural areas was 'agri-centric', while the ownership of land was a decisive factor when it comes to a landlord's status (see Baniowska 2003: 127).

${ }^{11}$ It was Cunegonde’s friend, Father Józef Czarnecki (1894-1949).

${ }^{12}$ When the whole village was in danger during World War II, a miracle happened owing to Cunegonde's prayer. The bridge, across which the German soldiers were driving, suddenly collapsed and they had to turn back.

\section{REFERENCES}

Adamowski, Jan 1999. Kategoria przestrzeni $w$ folklorze: Studium etnolingwistyczne. [The Category of Space in Folklore: An Ethnolinguistic Study.] Lublin: UMCS.

Agnes of Jesus 2014 = św. Teresa od Dzieciątka Jezus. Żótty zeszyt. Ostatnie rozmowy św. Teresy od Dzieciątka Jezus zebrane przez matkę Agnieszkę od Jezusa. [The Yellow Notebook. St. Thérèse of Child Jesus: Last Conversations Collected by Mother Agnes of Jesus.] Warszawa: Pax.

Baniowska, Ewa 2003. "Chłopski świat” w świetle ksiąg sądowych wiejskich. ['A Peasant's World' in the Light of Village Court Books.] In: J. Kowalska \& S. Szynkiewicz \& R. Tomicki (eds.) Czas zmiany, czas trwania: Studia etnologiczne. [Time of Change, Time of Endurance: Ethnological Studies.] Warszawa: IAiE PAN, pp. 117-132.

Bartkowski, Bronisław 2008. Miejsce mojego miłosierdzia i odpoczynku: Nadprzyrodzone oświecenia Kunegundy Siwiec ze Stryszawy zanotowane przez księdza Bronistawa Bartkowskiego. [The Place of My Mercy and Rest: Supernatural Enlightenments of Cunegonde Siwiec from Stryszawa, Noted by Father Bronisław Bartkowski.] Cracow: Wydawnictwo Karmelitów Bosych. Available at https://www.kundusia. pl/sites/default/files/MMMiO.pdf, last accessed on 12 October 2018.

Benedyktowicz, Zbigniew 2000. Portrety “obcego": Od stereotypu do symbolu. [Portraits of the Other: From Stereotype to Symbol.] Cracow: UJ. 
Bornemark, Joanna \& Ruin, Hans (eds.) 2012. Ambiguity of the Sacred: Phenomenology, Politics, Aesthetics. Södertörn Philosophical Studies, Vol. 12. Stockholm: Södertorn University.

Borowik, Irena 2003. Transformations of Catholicism and Religiosity of Catholics in Poland. In: I. Borowik (ed.) Religions, Churches and the Scientific Studies of Religion: Poland and Ukraine. Cracow: Nomos, pp. 41-59.

Bruce, Steve 2013 [2011]. Secularization: In Defence of an Unfashionable Theory. Oxford: Oxford University Press.

Caillois, Roger 2001. Man and the Sacred. Transl. by M. Barash. Urbana: University of Illinois Press.

Cameron, Euan 2010. Enchanted Europe: Superstition, Reason \& Religion 1250-1750. Oxford: Oxford University Press.

Czaczkowska, Ewa K. 2012. Siostra Faustyna: Biografia świętej. [Sister Faustina: The Biography of the Saint.] Cracow: Znak.

Donajska, Ryszarda 2014. Żyć Ewangelia: Biografia ks. Bronistawa Bartkowskiego spowiednika Stużebnicy Bożej Kunegundy Siwiec. [To Live by the Gospel: The Biography of Father Bronisław Bartkowski - the Confessor of Cunegonde Siwiec, the Servant of God.] Kraków: Wydawnictwo Karmelitów Bosych.

Eliade, Mircea 1997 [1988]. Historia wierzeń i idei religijnych. T. 1. Od epoki kamiennej ia do misteriów eleuzyńskich. [History of Religious Ideas. Vol. 1. From the Stone Age to the Eleusinian Mysteries.] Transl. by. S. Tokarski. Warszawa: PAX.

Exhumation = Ekshumacja Kunegundy Siwiec. [Exhumation of Cunegonde Siwiec.] Available at http://www.karmel.pl/ekshumacja-kunegundy-siwiec, last accessed on 11 October 2018.

Hukantaival, Sonja 2013. Finding Folk Religion: An Archaeology of 'Strange' Behaviour. Folklore: Electronic Journal of Folklore, Vol. 55, pp. 99-124. http://dx.doi. org/10.7592/FEJF2013.55.hukantaival.

Jakimowicz, Marcin 2009. Pocieszaj mnie, Kundusiu. [Comfort Me, Kundusia.] Gość Niedzielny, No. 24, 18 June. Available at http://gosc.pl/doc/803042.Pocieszaj-mnieKundusiu, last accessed on 11 October 2018.

Janicka-Krzywda, Urszula 2010. Górale Babiogórsy jako grupa etnograficzna. [Highlanders of Babia Mountain as an Ethnographic Group.] In: Urszula Janicka-Krzywda (ed.) Kultura ludowa Górali Babiogórskich. [Folk Culture of Highlanders from Babia Góra.] Cracow: Wierchy, pp. 23-36.

Kowalska, Faustyna 2000 [1981]. Dzienniczek: Miłosierdzie Boże w duszy mojej. [Diary: Divine Mercy in My Soul.] Warszawa: MIC.

Krzywda, Piotr 2010. Charakterystyka geograficzno-historyczna obszaru zamieszkiwanego przez Górali Babiogórskich. [The Geographical and Historical Characteristics of the Area Inhabited by Highlanders from Babia Góra.] In: U. Janicka-Krzywda (ed.) Kultura ludowa Górali Babiogórskich. [Folk Culture of Highlanders from Babia Góra.] Kraków: Wierchy, pp. 7-22.

Leśniewska, Ewa 2011. Kundusia z Siwcówki bliżej beatyfikacji. [Kundusia Closer to Beatification.] Gosc.pl, 30 October. Available at http://gosc.pl/doc/996945. Kundusia-z-Siwcowki-blizej-beatyfikacji, last accessed on 11 October 2018.

Orkan, Władysław 1946. Listy ze wsi i inne pisma społeczne: Wybór. [Letters from Rural Areas and Other Social Writing: A Selection.] Warszawa: Gebethner i Wolff. 
Otto, Rudolf 1958. The Idea of the Holy: An Inquiry into the Non-Rational Factor in the Idea of the Divine and Its Relation to the Rational. Transl. by J. W. Harvey. London \& Oxford \& New York: Oxford University Press.

Parsons, Talcott 1960. Structure and Process in Modern Societies. Glencoe, Ill.: The Free Press.

Rappaport, Roy 1999. Ritual and Religion in the Making of Humanity. Cambridge: Cambridge University Press. Available at https://zodml.org/sites/default/ files/\%5BRoy_A._Rappaport\%5D_Ritual_and_Religion_in_the_Maki.pdf, last accessed on 12 October 2018.

Riis, Ole \& Woodhead, Linda 2012 [2010]. A Sociology of Religious Emotion. Oxford: Oxford University Press.

Stinissen, Wilfrid 2001. Prosta droga do świętości: Śladem św. Teresyz Lisieux. [A Simple Path to Sanctity: In the Footsteps of St. Thérèse of Lisieux.] Poznań: W drodze.

Stomma, Ludwik 2002. Antropologia kultury wsi polskiej XIX w. oraz wybrane eseje. [Anthropology of Polish Folk Culture in the 19th Century: Selected Essays.] Łódź: Piotr Dopierała.

Thomas, William I. \& Znaniecki, Florian 1976 [1918]. Chtop polski w Europie i Ameryce. [The Polish Peasant in Europe and America.] Vol. 1. Warsaw: LSW.

Walczak, Andrzej 2002. Beskidzka katedra Prymasa Tysiąclecia. [The Beskid Cathedral of the Primate of the Millennium.] Stryszawa: Parafia św. Anny.

Waldenfels, Berhnard 2002. Topografia obcego. [Topography of the Other.] Transl. by J. Sidorek. Warszawa: Oficyna Naukowa.

Zieliński, Jerzy (ed.) 2010. Piękno ukryte w prostocie: Życie Stużebnicy Bożej Kunegundy Siwiec OCDS. [Beauty Hidden in Simplicity: The Life of the Servant of God Cunegonde Siwiec OCDS.] Cracow: Wydawnictwo Karmelitów Bosych. 